\title{
TRANSAKCJE NA RYNKU NIERUCHOMOŚCI W UNIEJOWIE W LATACH 2007-2015
}

Zarys treści: Artykuł przedstawia wyniki analiz obejmujących zrealizowane w latach 2007-2015 transakcje kupna-sprzedaży nieruchomości zlokalizowanych w granicach administracyjnych Uniejowa. Jego celem jest identyfikacja rodzajów nieruchomości będących przedmiotem transakcji kupna-sprzedaży wraz z ich lokalizacją oraz ukazanie ogólnej sytuacji na rynku nieruchomości na badanym obszarze. Uniejów

Słowa kluczowe: nieruchomość, rynek nieruchomości, transakcje kupna-sprzedaży,

\section{WPROWADZENIE}

Rynek nieruchomości to miejsce, gdzie odbywa się transfer praw do nieruchomości oraz są zawierane umowy kupna-sprzedaży. Obejmuje on zarówno podmioty rynkowe jak i przedmioty rynkowe. Podmiotem rynkowym jest osoba sprzedająca i inwestująca $\mathrm{w}$ nieruchomość natomiast przedmiotem rynkowym jest sama nieruchomość lub składniki majątkowe ${ }^{1}$.

Przedmiotem publikacji jest analiza transakcji kupna-sprzedaży nieruchomości zlokalizowanych w granicach administracyjnych Uniejowa. Obejmuje ona okres 2007-2015 i w dużej mierze opiera się na danych udostępnionych ze Starostwa Powiatowego w Poddębicach. Celem artykułu jest ukazanie tendencji

\footnotetext{
* mgr Paula Bączyk, absolwentka, Uniwersytet Łódzki, Wydział Nauk Geograficznych i Wydział Zarządzania, e-mail: paula93baczyk@gmail.com.

** dr Edyta Masierek, adiunkt, Uniwersytet Łódzki, Wydział Nauk Geograficznych, Instytut Zagospodarowania Środowiska i Polityki Przestrzennej, 90-142 Łódź, ul. Kopcińskiego 31, e-mail: edyta.masierek@geo.uni.lodz.pl.

1 E. Kucharska-Stasiak, Nieruchomość a rynek, Wyd. Naukowe PWN, Warszawa 1997.
} 
i rozmieszczenia w przestrzeni nieruchomości, które były przedmiotem transakcji. Zgodnie z art. 46 Kodeksu cywilnego „nieruchomościami są części powierzchni ziemskiej stanowiące odrębny przedmiot własności, określane mianem gruntów, jak również budynki trwale z gruntem związane lub części takich budynków (lokale), jeżeli na mocy przepisów szczególnych stanowią odrębny od gruntu przedmiot własności”'2. Wyróżniamy nieruchomości gruntowe (zabudowane i niezabudowane), lokalowe i budynkowe. Nieruchomościami gruntowymi są ,grunty wraz z jego częściami składowymi tzn. naniesieniami w postaci budynków czy budowli jeżeli nie stanowią one odrębnego przedmiotu własności"’3. Wśród nich wskazać można te zabudowane, czyli takie, na których dokonano procesu budowlanego, w wyniku którego powstało naniesienie trwale związane z gruntem i stanowiące ten sam co grunt, przedmiot własności $\mathrm{i}^{4}$.

Nieruchomość budynkowa z kolei powstaje w wyniku prawnego oddzielenia budynku od gruntu nieruchomości zabudowanej. Sam grunt jest przedmiotem prawa użytkowania wieczystego, a budynki przedmiotem prawa własności. Budynek lub budowla znajdująca się na działce stanowi odrębny przedmiot własności. Nieruchomość lokalową stanowi natomiast samodzielny lokal mieszkalny lub niemieszkalny wykorzystywany zgodnie ze swoim przeznaczeniem ${ }^{5}$.

Opracowanie obejmuje nieruchomości w podziale na:

- gruntowe zabudowane i niezabudowane (z wykluczeniem nieruchomości rolnych i leśnych), lokalowe oraz budynkowe;

- gminne i prywatne;

- o funkcji mieszkaniowej, komercyjnej (funkcje usługowe w tym sklepy, biura, hotele, obiekty gastronomiczne, obiekty rekreacyjne itd.), oraz nieruchomości o funkcji przemysłowej (rozumiane jako obiekty produkcyjne, hale i magazyny) ${ }^{6}$.

$\mathrm{W}$ artykule wykorzystane zostało również pojęcie form władania nieruchomościami, które rozumie się jako określone możliwości właściciela w stosunku do nieruchomości. Można wyróżnić własność prywatną, która dotyczy osób prawnych i fizycznych oraz publiczną, która odnosi się do nieruchomości Skarbu Państwa i jednostek samorządu terytorialnego ${ }^{7}$. Użyte do analizy w pracy zostały również pojęcia dotyczące form obrotu nieruchomościami na rynku nie-

2 Kodeks Cywilny (Dz.U. 2018, poz. 1025, 1104, 1629, 2073, 2244; Dz.U. 2019, poz. 80), art. 46 , par. 1 .

3 Ustawa z dnia 21 sierpnia 1997 r. o gospodarce nieruchomościami (Dz.U. 2018, poz. 2204, 2348; Dz.U. 2019, poz. 270) art. 4, pkt 1.

4 M. Bryx (red.), Podstawy zarządzania nieruchomościami, Wyd. Poltex, Warszawa 2009.

5 Tamże.

6 E. Kucharska-Stasiak, Nieruchomości w gospodarce rynkowej, Wyd. Naukowe PWN, Warszawa 2006.

7 A. Pawlikowska-Piechotka, Gospodarka nieruchomościami, PCB, Warszawa 1999. 
ruchomości. Wyróżniono formy obrotu na wolnym rynku, przetargi oraz formy bezprzetargowe ${ }^{8}$.

Publikacja powstała na podstawie pracy magisterskiej pt. „Rynek nieruchomości Uniejowa w latach 2007-2015 - kontekst zagospodarowania” napisanej w Instytucie Zagospodarowania Środowiska i Polityki Przestrzennej w 2017 r. Podstawowe źródło opracowania stanowią udostępnione w grudniu 2015 r. dane ze Starostwa Powiatowego w Poddębicach dotyczące transakcji kupna-sprzedaży nieruchomości, które zostały zrealizowane w latach 2007-2015 w granicach administracyjnych miasta Uniejowa. Informacje te zostały zagregowane, podzielone na właściwe kategorie, a następnie uzupełnione o dane zebrane podczas wizji lokalnej przeprowadzonej w październiku 2016 oraz w kwietniu 2017 r. w terenie. Część danych przestawiono w postaci opracowań kartograficznych, na których dokonano prezentacji rozmieszczenia w przestrzeni nieruchomości, które były przedmiotem transakcji.

\section{TRANSAKCJE KUPNA-SPRZEDAŻY NIERUCHOMOŚCI W UNIEJOWIE W LATACH 2007-2015}

Udostępnione przez Starostwo Powiatowe w Poddębicach informacje pozwoliły na wyodrębnienie i analizę transakcji kupna-sprzedaży nieruchomości w Uniejowie w latach 2007-2015 ze względu na ich rodzaj, wartość, strukturę własnościową, podmioty biorące udział w transakcjach oraz formy zbywania nieruchomości.

\section{Rodzaje nieruchomości stanowiące przedmiot transakcji}

Jeśli chodzi o rodzaj nieruchomości będących przedmiotem transakcji podzielone one zostały na potrzeby badania na gruntowe (zabudowane i niezabudowane), lokalowe i budynkowe. W latach 2007-2015 ponad połowa transakcji dotyczyła nieruchomości gruntowych, wśród nich 78,9\% stanowiły nieruchomości gruntowe zabudowane. Następną liczną grupę reprezentowały transakcje kupna-sprzedaży nieruchomości lokalowych tj. 46,4\% ogółu. Najmniej transakcji natomiast dokonano w ramach nieruchomości budynkowych zaledwie $2,9 \%$ (ryc. 1 ).

8 J. Skoczeń, 2015, www.strefynieruchomosci.blog.pl [dostęp: 5.05.2017]; Ustawa z dnia 21 sierpnia 1997 r. o gospodarce nieruchomościami (Dz.U. 2018, poz. 2204, 2348; Dz.U. 2019, poz. 270). 


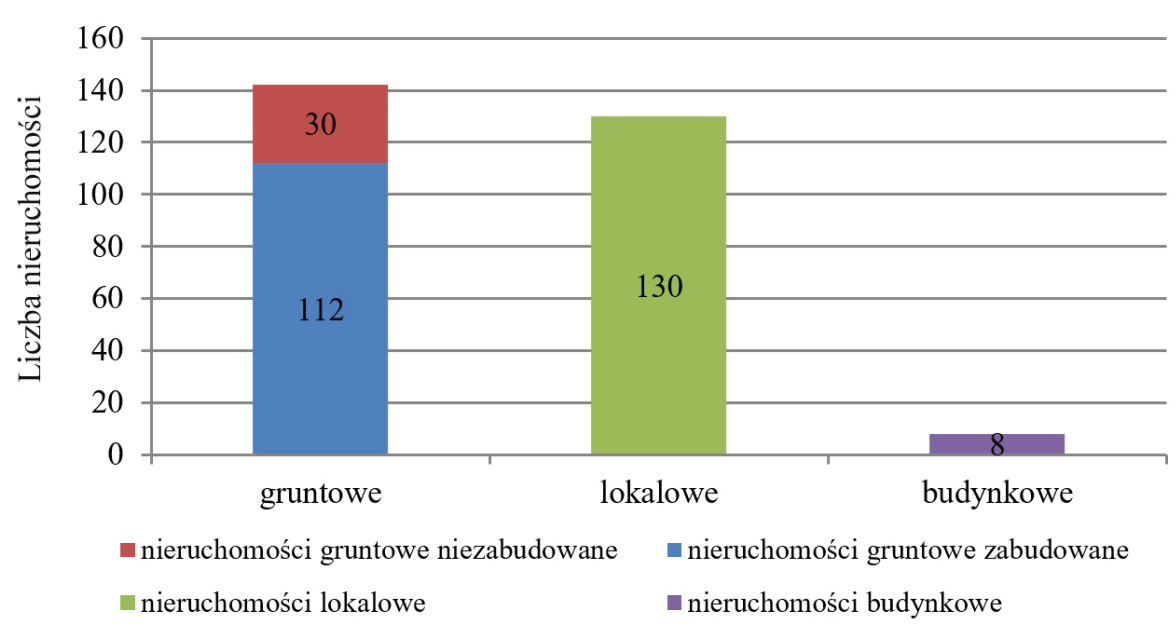

Ryc. 1. Liczba nieruchomości stanowiąca przedmiot transakcji

kupna-sprzedaży w Uniejowie w latach 2007-2015

Źródło: opracowanie własne na podstawie danych

ze Starostwa Powiatowego w Poddębicach, 2015

Odnosząc się do nieruchomości lokalowych, warto zwrócić uwagę na gwałtowny wzrost zainteresowania nimi w 2013 i 2015 roku (ryc. 2). W tych latach widać również znaczną przewagę transakcji dotyczących tego rodzaju nieruchomości nad pozostałymi. Było to związane m.in. z oddaniem do użytkowania budynków mieszkaniowych wielorodzinnych zrealizowanych przez prywatnego inwestora „PGK - Termy Uniejów Sp. z o.o.” zlokalizowanych przy ulicach Targowej i Reymonta w Uniejowie'. W analizowanym okresie dużym zainteresowaniem nabywców cieszyły się również nieruchomości gruntowe, szczególnie w pierwszych trzech latach objętych analizą, tj. od 2007 do 2009 roku.

Najwięcej transakcji zaobserwować można w strefie zurbanizowanej, zwłaszcza na terenach przeznaczonych pod zabudowę planowaną lub już istniejącą ${ }^{10}$. W celu przedstawienia lokalizacji analizowanych transakcji dokonano podziału struktury miasta na cztery podobszary A, B, C i D (ryc. 3). W podobszarze A w głównej mierze dokonywane były transakcje dotyczące nieruchomości gruntowych niezabudowanych. Ogólnie najwięcej transakcji kupna-sprzedaży nieruchomości (w szczególności gruntowych zabudowanych) zlokalizowanych było w kwadracie B. Rozmieszczone są one nieregularnie, po całym obszarze wytyczonego kwadratu. $\mathrm{W}$ podobszarze $\mathrm{C}$ również w przewadze występowały

9 Wójcik T., Czeka Nas dużo pracy, wywiad z panem Józefem Kaczmarkiem, burmistrzem Uniejowa, „W Uniejowie, Pismo Towarzystwa Przyjaciół Uniejowa”, red. M. Charuba i in., Uniejów 2015.

${ }^{10}$ Zmiany Studium uwarunkowań i kierunków zagospodarowania przestrzennego miasta i gminy Uniejów, Uniejów 2007. 
transakcje przedmiotem których były nieruchomości gruntowe zabudowane. W jego zachodniej oraz północno-zachodniej części występują nieruchomości gruntowe niezabudowane, których przeznaczenie jest ściśle związane z pełnieniem funkcji leczniczo-uzdrowiskowej, gastronomicznej czy hotelarskiej. Podobszar D obejmuje natomiast jedynie transakcje dotyczące nieruchomości gruntowych zabudowanych. W obszarze tym dokonało się najmniej transakcji. Ich lokalizacja dotyczy jedynie zachodniej części odcinka drogi głównej Uniejowa.

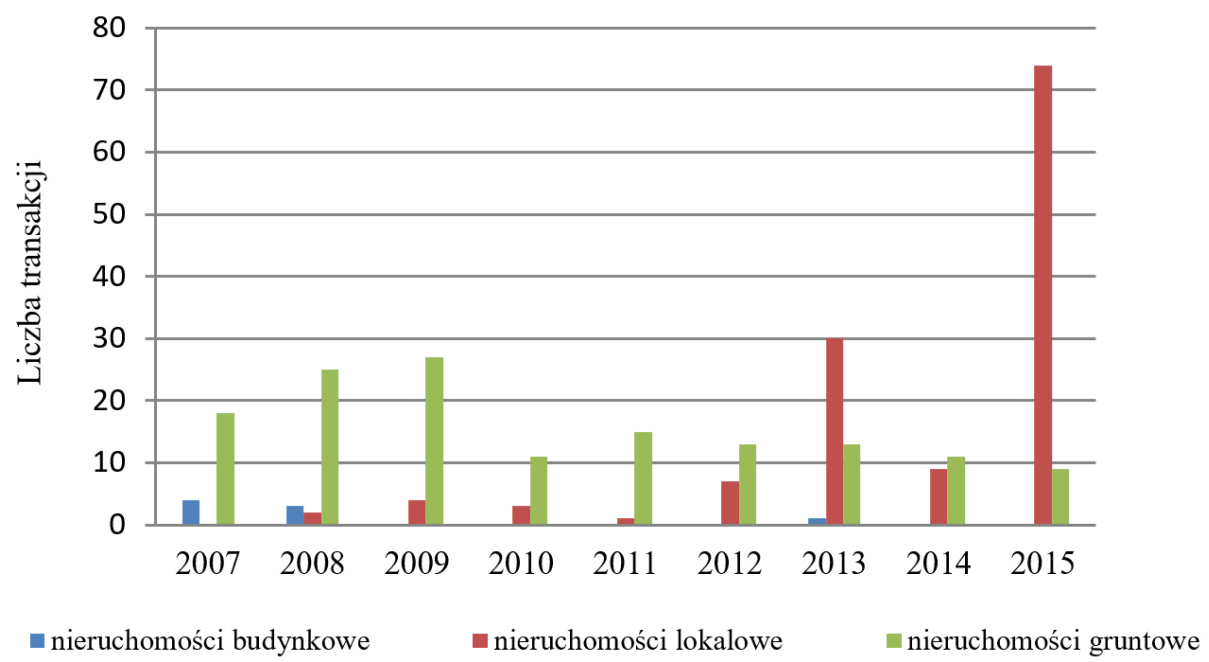

Ryc. 2. Nieruchomości stanowiące przedmiot transakcji kupna-sprzedaży w Uniejowie w latach 2007-2015

Źródło: opracowanie własne na podstawie danych

ze Starostwa Powiatowego w Poddębicach, 2015

\section{Formy zbywania nieruchomości}

Analizując strukturę własności nieruchomości w całym Uniejowie warto zauważyć, iż przeważają tu grunty prywatne, które stanowią $74,1 \%$ powierzchni miasta. Następną grupę reprezentuje własność komunalna (11,9\%) oraz tereny należące do Skarbu Państwa $(10,9 \%)^{11}$. W artykule dokonano podziału nieruchomości, przyjmując jako kryterium rodzaj podmiotu sprzedającego: podmiot prywatny (z podziałem na osobę fizyczną i prawną) i podmiot publiczny, a następnie $\mathrm{w}$ tych kategoriach dokonano pogrupowania. Na potrzeby analizy do nieruchomości prywatnych w kategorii „osoba prawna” zaliczono spółdzielnię mieszkaniową i spółkę komunalną.

${ }^{11}$ Projekt Lokalnego Programu Rewitalizacji Gminy i Miasta Uniejów na lata 2017-2025, 2017. 


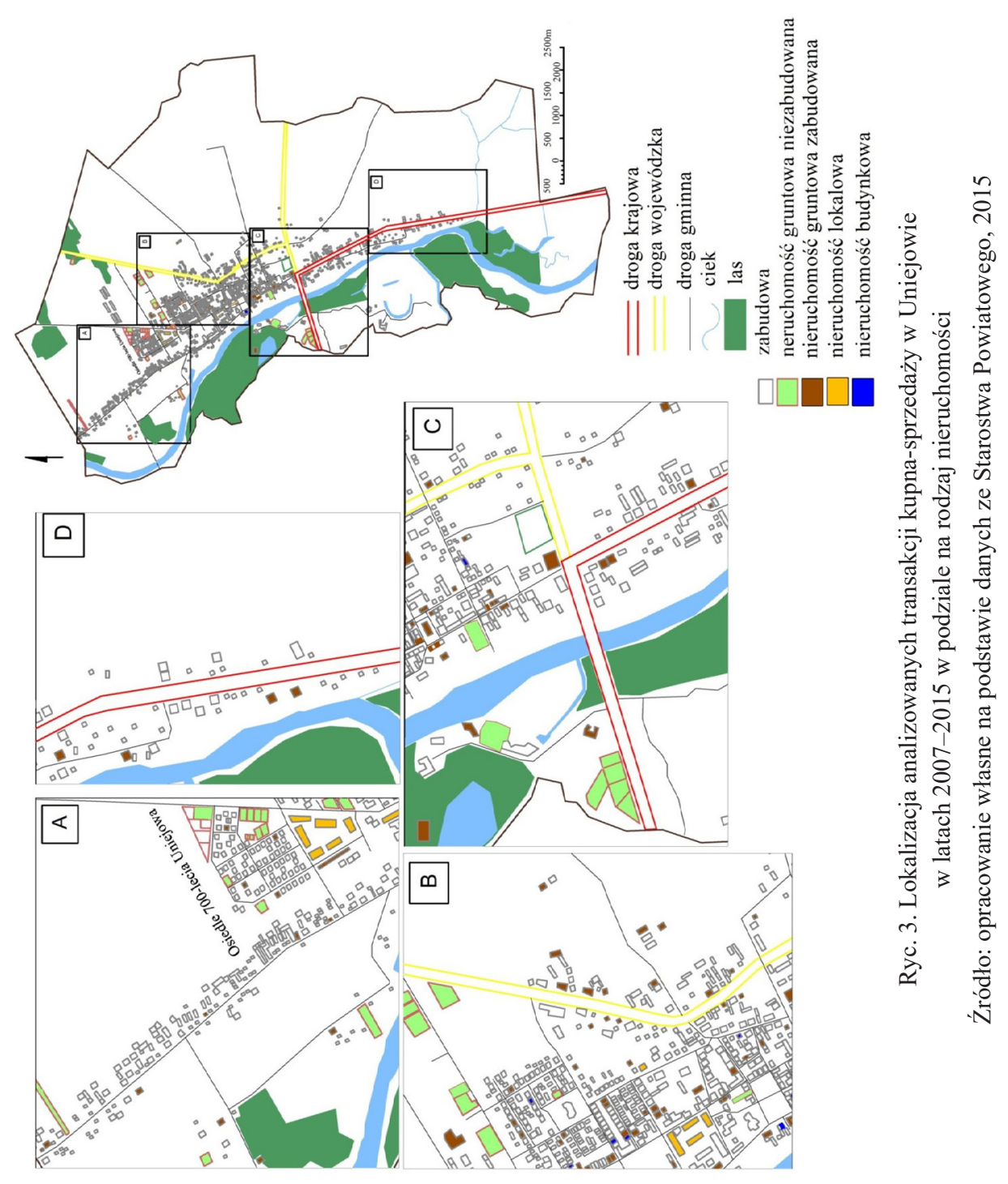


Gospodarowanie w zakresie nieruchomości stanowiących własność prywatną odbywa się na podstawie Kodeksu Cywilnego. Nieruchomości stanowiące zasób prywatny mogą być zbywane w sposób natychmiastowy, na wolnym rynku. Kupujący i sprzedający dobrowolnie określają warunki najkorzystniejsze dla stron transakcji ${ }^{12}$. Natomiast gospodarowanie nieruchomościami publicznymi następuje zgodnie $\mathrm{z}$ Ustawą o gospodarce nieruchomościami ${ }^{13}$ i jest związane z prowadzeniem procedury przetargowej. Organizacja przetargów związana jest z chęcią uzyskania najwyższej ceny, wyboru najkorzystniejszej oferty czy dokonania pełnej identyfikacji potencjalnego nabywcy.

W ogłoszeniu o przetargu muszą znajdować się m.in. następujące informacje:

- cena umieszczona w wykazie oraz cena wywoławcza nieruchomości;

- obciążenia nieruchomości oraz zobowiązania, których przedmiotem jest dana nieruchomość;

- termin i miejsce przeprowadzania przetargu;

- dane dotyczące wysokości wadium, jego formy, terminu i miejsca wniesienia $^{14}$

W określonych przypadkach dopuszczalna jest także forma bezprzetargowa zbywania nieruchomości publicznych np.:

- na rzecz osoby, której przysługuje pierwszeństwo w jej nabyciu;

- spadkobiercy;

- najemcy lokalu mieszkalnego, a najem został nawiązany na czas nieoznaczony;

- $\quad$ sprzedaży między Skarbem Państwa a jednostką samorządu terytorialnego;

- jeżeli zbycie następuje w drodze zamiany lub darowizny;

- sprzedaż nieruchomości następuje na rzecz jej użytkownika wieczystego;

- gdy nieruchomość ma stanowić wkład niepieniężny do spółki, wyposażenie nowo tworzonej państwowej lub samorządowej osoby prawnej, lub stanowi majątek tworzonej fundacji ${ }^{15}$.

Dane ze Starostwa Powiatowego dla badanego okresu wskazują na przewagę prywatnych nieruchomości będących przedmiotem transakcji w latach 2007-2015, które stanowią aż 85,7\% ogółu. Najwięcej transakcji w ramach nieruchomości prywatnych (57\%) zachodziło pomiędzy podmiotami prywatnymi w postaci osób fizycznych zarówno po stronie kupującej jak i sprzedającej (tab. 1). W następnej kolejności występowały transakcje, w których osobą sprzedającą była osoba prawna a kupującą fizyczna (33\%). W tym przypadku w większości dotyczyło to

12 J. Skoczeń, 2015, http://strefynieruchomosci.blog.pl/ [dostęp: 5.05.2017].

${ }^{13} \mathrm{http}: / /$ prawoanieruchomosci.pl/ [dostęp: 18.01.2017].

${ }^{14}$ Ustawa z dnia 21 sierpnia 1997 r. o gospodarce nieruchomościami (Dz.U. 2018, poz. 2204, 2348, Dz.U. 2019, poz. 270), art. 38 ust. 2.

15 Ustawa z dnia 21 sierpnia 1997 r. o gospodarce nieruchomościami (Dz.U. 2018, poz. 2204, 2348, Dz.U. 2019, poz. 270). 
sprzedaży przez dewelopera nowych lokali mieszkaniowych. W 10. transakcjach stronę stanowiła Spółdzielnia Mieszkaniowa „Tęcza”, która ustanawiała odrębną własność do lokalu i dokonywała przeniesienia prawa własności na osobę fizyczną.

Tabela 1. Strony transakcji kupna-sprzedaży nieruchomości prywatnych w Uniejowie w okresie 2007-2015

\begin{tabular}{|l|c|c|c|}
\hline Strona sprzedająca & Strona kupująca & $\begin{array}{c}\text { Liczba } \\
\text { transakcji }\end{array}$ & $\begin{array}{c}\text { Transakcje } \\
{[\%]}\end{array}$ \\
\hline \multirow{3}{*}{ Osoba prawna } & Osoba prawna & 4 & 1,7 \\
\cline { 2 - 4 } & Osoba fizyczna & 79 & 32,9 \\
\cline { 2 - 4 } & Gmina Uniejów & 9 & 3,7 \\
\hline $\begin{array}{l}\text { Osoba prawna - } \\
\text { Spółdzielnia mieszkaniowa }\end{array}$ & Osoba fizyczna & 10 & 4,2 \\
\hline \multirow{3}{*}{ Osoba fizyczna } & Osoba fizyczna & 136 & 56,7 \\
\cline { 2 - 4 } & Osoba prawna & 1 & 0,4 \\
\cline { 2 - 4 } & Gmina Uniejów & 1 & 0,4 \\
\hline Razem & $\mathrm{x}$ & 240 & 100,0 \\
\hline
\end{tabular}

Źródło: opracowanie własne na podstawie danych ze Starostwa Powiatowego w Poddębicach, 2015

Jeśli chodzi o transakcje, które dokonały się w badanym okresie w ramach nieruchomości publicznych to najczęściej stronę sprzedającą stanowiła gmina, jako właściciel terenów. W zdecydowanej większości przypadków zbycie następowało na rzecz osób fizycznych. Jedynie dwie transakcje odbyły się pomiędzy Gminą Uniejów a Skarbem Państwa (tab. 2).

Tabela 2. Strony analizowanych transakcji kupna-sprzedaży nieruchomości publicznych w Uniejowie w latach 2007-2015

\begin{tabular}{|c|c|c|c|}
\hline $\begin{array}{c}\text { Osoba } \\
\text { sprzedająca }\end{array}$ & $\begin{array}{c}\text { Osoba } \\
\text { kupująca }\end{array}$ & Transakcje & Transakcje [\%] \\
\hline Gmina Uniejów & Osoba fizyczna & 29 & 72,5 \\
\hline Gmina Uniejów & Osoba prawna & 9 & 22,5 \\
\hline Skarb Państwa & Gmina Uniejów & 2 & 5,0 \\
\hline Razem & $\mathrm{x}$ & 40 & 100,0 \\
\hline
\end{tabular}

Źródło: opracowanie własne na podstawie danych ze Starostwa Powiatowego w Poddębicach, 2015

Sposób w jaki zbywana jest nieruchomość uzależniony jest w dużej mierze od rodzaju podmiotu sprzedającego nieruchomość. Na potrzeby analizy wyod- 
rębniono trzy formy zbywania nieruchomości: przetargowa, bezprzetargowa i na wolnym rynku.

W 2014 roku w Polsce transakcje przeprowadzane na wolnym rynku stanowiły około 90\% (pod względem liczby) i około 92\% (pod względem wartości) ogółu transakcji dotyczących kupna-sprzedaży nieruchomości ${ }^{16}$. Podobnie było w przypadku badanych nieruchomości. Zdecydowana większość transakcji, bo aż $93,2 \%$ dotyczyła tej właśnie formy obrotu nieruchomościami, co wynika m.in. z wcześniej wspomnianej struktury własnościowej nieruchomości. Dla około $6 \%$ spośród wszystkich analizowanych przeprowadzono procedurę przetargową (ryc. 4) (tab. 4).

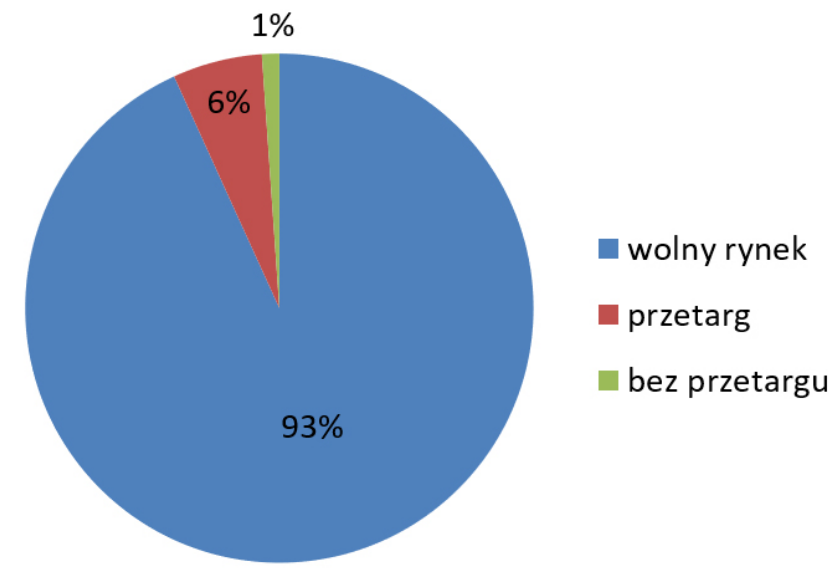

Ryc. 4. Formy sprzedaży nieruchomości w Uniejowie w latach 2007-2015

Źródło: opracowanie własne na podstawie danych ze Starostwa Powiatowego w Poddębicach, 2015

W drodze przetargu dokonywano głównie sprzedaży nieruchomości niezabudowanych (tab. 3). Miasto zbywało m.in. działki ${ }^{17}$, które w Studium uwarunkowań i kierunków zagospodarowania przestrzennego Uniejowa ${ }^{18}$ określone zostały jako rozwojowe obszary jednorodzinnej zabudowy mieszkaniowej. Są one zlokalizowane na północ od Osiedla 700-lecia Uniejowa. Prowadzenie aktywnej sprzedaży nieruchomości niezabudowanych odzwierciedla także w pewien sposób

${ }^{16}$ Obrót nieruchomościami w 2014, Główny Urząd Statystyczny GUS, Warszawa 2015.

${ }_{17}$ Zarzadzenie nr 97/2015 Burmistrza Miasta Uniejów z dnia 8 października $2015 \mathrm{r}$. w sprawie ogłoszenia o II-gim ustnym przetargu nieograniczonym na sprzedaż dziatek z przeznaczeniem pod budownictwo mieszkaniowe jednorodzinne.

${ }_{18}$ Zmiany Studium uwarunkowań i kierunków zagospodarowania przestrzennego miasta i gminy Uniejów, Uniejów 2007. 
prowadzoną politykę rozwoju miasta w kierunku północnym ${ }^{19}$. Zapisy Studium dzielą wyraźnie miasto na pięć różnych stref:

- strefę urbanizacji,

- ochrony uzdrowiskowej,

- ochrony rolniczej przestrzeni produkcyjnej,

- ochrony wartości kulturowych,

- ochrony ekologicznej.

Tabela 3. Formy sprzedaży nieruchomości w Uniejowie w latach 2007-2015 z uwzględnieniem ich rodzaju

\begin{tabular}{|l|c|c|c|c|c|}
\hline \multirow{2}{*}{$\begin{array}{l}\text { Rodzaj } \\
\text { nieruchomości }\end{array}$} & Prywatna & \multicolumn{2}{|c|}{ Publiczna } & \multicolumn{2}{|c|}{$\begin{array}{c}\text { Transakcje } \\
\text { ogółem }\end{array}$} \\
\cline { 2 - 4 } \cline { 6 - 7 } & $\begin{array}{c}\text { Sprzedaż } \\
\text { na wolnym } \\
\text { rynku }\end{array}$ & $\begin{array}{c}\text { Sprzedaż } \\
\text { w drodze } \\
\text { przetargu }\end{array}$ & $\begin{array}{c}\text { Sprzedaż } \\
\text { bezprzetargowa }\end{array}$ & Liczba & $\%$ \\
\hline Lokalowa & 129 & 0 & 1 & 130 & 46 \\
\hline Budynkowa & 8 & 0 & 0 & 8 & 3 \\
\hline $\begin{array}{l}\text { Gruntowa } \\
\text { zabudowana }\end{array}$ & 108 & 3 & 1 & 112 & 40 \\
\hline $\begin{array}{l}\text { Gruntowa } \\
\text { niezabudowana }\end{array}$ & 16 & 13 & 3 & 280 & 100 \\
\hline Razem & 261 & 16 & & & 11 \\
\hline
\end{tabular}

Źródło: opracowanie własne na podstawie danych ze Starostwa Powiatowego, 2015

Mające miejsce przetargi dotyczyły również nieruchomości zabudowanych. W 2012 roku miała miejsce sprzedaż nieruchomości gruntowej z zabudową w postaci budynku gastronomicznego z zapleczem, kuchnią i obiektem gospodarczym. W wyniku przeprowadzonego przetargu Spółka PGK Termy Uniejów zaprzestała prowadzenia działalności gospodarczej na rzecz właścicieli rodzinnej firmy MIPAMA. Obecnie obiekt ten łączy w sobie restaurację i kawiarnię ${ }^{20}$. W 2013 roku odbył się przetarg dotyczący sprzedaży nieruchomości gminnej w postaci „Kasztelu Rycerskiego”. Opisywana nieruchomość zlokalizowana jest w obszarze ochrony NATURA 2000 na terenie Nadwarciańskiego obszaru chronionego krajobrazu oraz w strefie uzdrowiskowej A (ryc. 3., zachodnia granica podobszaru C), na terenach wskazanych do zabudowy z zakresu lecznictwa

${ }^{19} \mathrm{~K}$. Milewska-Osiecka, A. Ogrodowczyk, Budownictwo $i$ warunki mieszkaniowe na terenie miasta Uniejów, „Biuletyn Uniejowski” 2014, t. 3, s. 35-51.

${ }^{20} \mathrm{http}: / /$ www.termalna.com.pl/ [dostęp: 19.05.2017], http://www.uniejow.net.pl/ [dostęp: 19.05.2017]. 
uzdrowiskowego, sportu i rekreacji. Jego sposób użytkowania związany jest z prowadzeniem działalności w zakresie hotelarstwa, gastronomii, lecznictwa uzdrowiskowego, sportu i rekreacji ${ }^{21}$. W 2010 roku nastąpiła także sprzedaż nieruchomości zabudowanej kompleksem leczniczo-rehabilitacyjnym. Obecnie obiekt ten oferuje usługi medyczne i rehabilitacyjne ${ }^{22}$.

Tabela 4. Struktura średniej powierzchni użytkowej i cen lokali mieszkalnych na rynku pierwotnym w Uniejowie w analizowanym okresie

\begin{tabular}{|l|c|c|}
\hline \multirow{2}{*}{ Wskaźnik } & \multicolumn{2}{|c|}{ Nieruchomości lokalowe o funkcji mieszkaniowej } \\
\cline { 2 - 3 } & Rynek pierwotny & Rynek wtórny \\
\hline $\begin{array}{l}\text { Średnia powierzchnia } \\
\text { użytkowa }\left[\mathrm{m}^{2}\right]\end{array}$ & 51,2 & 45,0 \\
\hline $\begin{array}{l}\text { Średnia wartość } \\
\text { nieruchomości }\left[\mathrm{z} / \mathrm{m}^{2}\right]\end{array}$ & 3183,5 & 2906,1 \\
\hline
\end{tabular}

Źródło: opracowanie własne na podstawie danych ze Starostwa Powiatowego w Poddębicach, 2015 i stron internetowych: http://www.dzienniklodzki.pl/ [dostęp: 20.05.2017], http://uniejow. pl/o-gminie/spolki-gminne/ [dostęp: 20.05.2017]

Łączna liczba analizowanych transakcji wynosiła 280. Przedmiotem zdecydowanej większości z nich pozostawały nieruchomości lokalowe (130) tj. 46\% ogółu transakcji. Wśród nich jedynie jedna stanowiła nieruchomość publiczną nabytą w formie bezprzetargowej. Nieruchomości gruntowe zabudowane stanowiły $40 \%$ ogółu transakcji (108). W analizowanym okresie dokonano także 16 transakcji kupna - sprzedaży nieruchomości publicznych w drodze przetargu, co stanowiło jedynie około $6 \%$ ich ogólnej liczby. Najmniej liczna była grupa nieruchomości budynkowych (8), która stanowiła zaledwie 3\% wszystkich transakcji i każda z nich dokonana została na wolnym rynku (tab. 3 ).

\section{Lokale mieszkalne - średnia powierzchnia i cena transakcyjna}

Ostatni dokonany podział analizowanych transakcji dotyczy ich cen, które zależą od różnych czynników. Należą do nich m.in. lokalizacja, możliwość wykorzystania nieruchomości, jej wielkość, liczba właścicieli czy obciążenia związane z daną nieruchomością. Istotnym czynnikiem jest również relacja popytu i podaży oceniana na podstawie sytuacji rynkowej, analizy cen i koniunktury,

${ }^{21}$ Zarzadzenie Nr 46/2013 Burmistrza miasta Uniejów z dnia 2 lipca 2013 w sprawie ogłoszenia o przetargu nieograniczonym na sprzedaż na własność nieruchomości gminy Uniejów.

${ }^{22} \mathrm{http} / / / w w w . i z c . p l /$ uniejow/nasz-osrodek.html [dostęp: 19.05.2017]. 
a także czasem forma transakcji np. jej przebieg i charakter ma wpływ na ostateczną cenę nieruchomości ${ }^{23}$.

Udostępnione dane dotyczące kwot poszczególnych transakcji wykorzystane zostały do przedstawienia nieruchomości w strukturze przestrzennej miasta i tym samym ukazania zależności pomiędzy ich lokalizacją, funkcją i ceną. Na ich podstawie dokonano zestawienia cen transakcyjnych analizowanych nieruchomości. Przy ich podziale ze względu na sposób użytkowania posłużono się zasadami stosowanymi przez E. Kucharską-Stasiak (2006) i wyodrębniono: nieruchomości o funkcji mieszkaniowej, komercyjnej czy przemysłowej. Utworzono również kategorię ,inne”, do której zaliczono pozostałe nieruchomości np. garaże czy obiekty gospodarcze.

$\mathrm{W}$ analizie cen przedstawione zostały nieruchomości ze względu na ich strukturę rodzajową i pełnioną funkcję (mieszkaniowa i komercyjna). W badanym okresie dokonano 126 transakcji kupna-sprzedaży lokali mieszkaniowych. W dużej mierze były to transakcje przeprowadzone na rynku pierwotnym. Średnia powierzchnia użytkowa wspomnianych lokali na rynku pierwotnym wynosiła $51,2 \mathrm{~m}^{2}$. Były to głównie lokale mieszkalne zlokalizowane we wcześniej opisanych, nowych budynkach zabudowy wielorodzinnej. Średnia cena analizowanych lokali mieszkalnych wynosiła $3183,5 \mathrm{zz} / \mathrm{m}^{2}$. Na rynku wtórnym z kolei średnia powierzchnia użytkowa wynosiła $45 \mathrm{~m}^{2}$, a kwota za metr kwadratowy $2906,1 \mathrm{zl}$ (tab. 4).

W celu ukazania lokalizacji nieruchomości lokalowych stanowiących przedmiot transakcji oraz ich średnich cen wydzielono z obszaru miasta dwa kwadraty A i B (rys. 5). Kwadrat A obejmuje obszar na północy miasta zawierający głównie zabudowę wielorodzinną. W jego centralnej części zlokalizowanych jest sześć bloków mieszkaniowych wielorodzinnych, w których mieszczą się lokale będące przedmiotami transakcji. Najdroższe lokale mieszkaniowe znajdują się w nowym budownictwie. Ich ceny klasyfikują się w przedziale od $3000-3500 \mathrm{z} / \mathrm{m}^{2}$ powierzchni użytkowej. W sąsiedztwie nowej zabudowy zlokalizowana jest również starsza zabudowa wielorodzinna. Spośród analizowanych transakcji 10 lokali mieszkaniowych znajduje się w tej właśnie lokalizacji. Ceny tych nieruchomości mieszczą się w zakresie od 2500 do $3000 \mathrm{zz} / \mathrm{m}^{2}$. Ponadto w kwadracie B znajduje się zabudowa wielorodzinna, w której zlokalizowane są niektóre z analizowanych nieruchomości lokalowych. Ich ceny są zróżnicowane i wahają się od 2500 do $3500 \mathrm{zł} / \mathrm{m}^{2}$. W północno-wschodniej części kwadratu B zlokalizowane są nieruchomości lokalowe, które zaliczone są do najtańszych. Ich ceny za metr kwadratowy wynoszą do $2000 \mathrm{z}$.

${ }^{23}$ A. Pawlikowska-Piechotka, Gospodarka nieruchomościami, Warszawa 1999. 


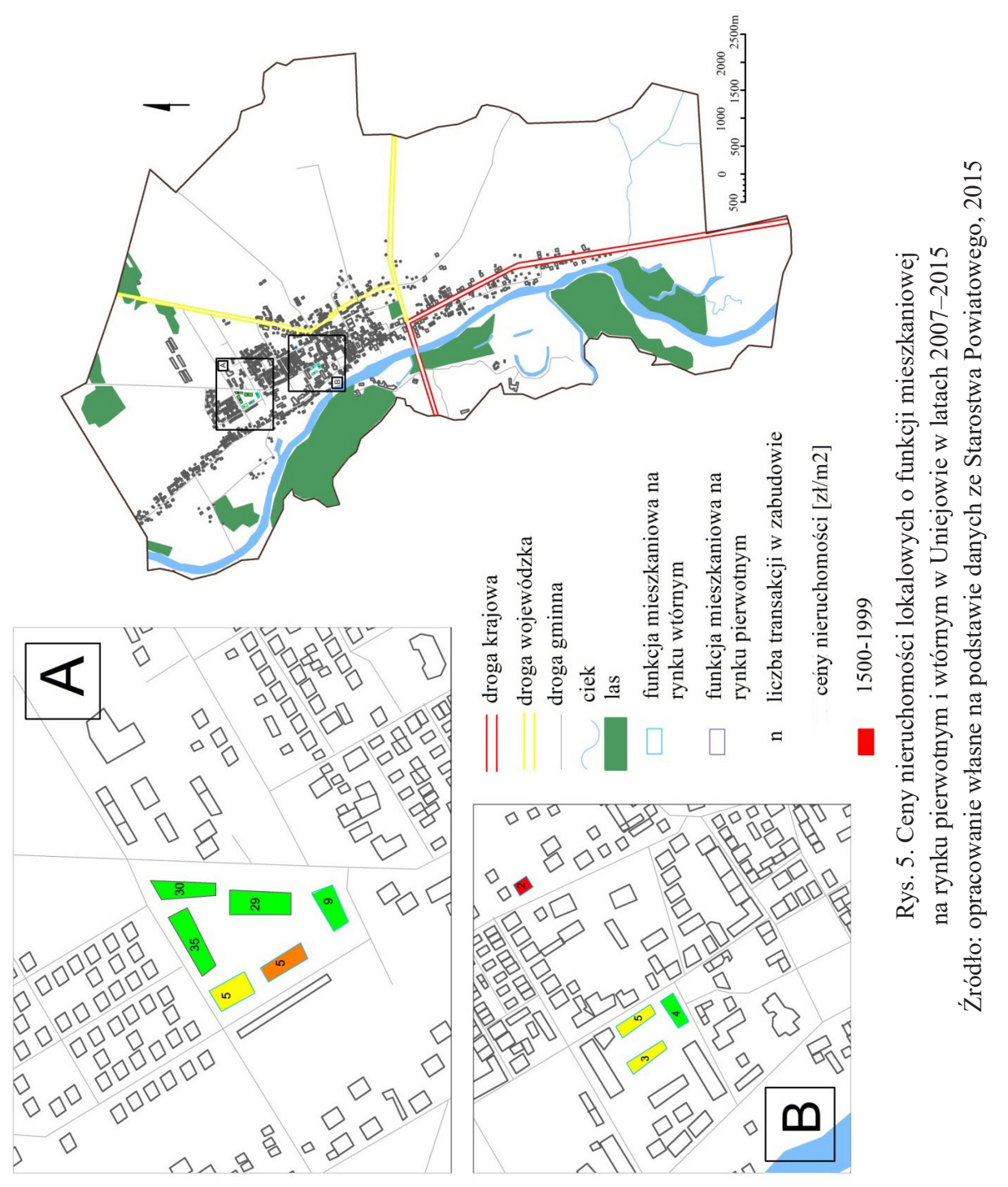


Przedmiotem 112 transakcji były nieruchomości gruntowe zabudowane, natomiast 31 niezabudowane. Ze względu na przeznaczenie można wyróżnić nieruchomości gruntowe zabudowane o funkcji mieszkaniowej, komercyjnej (w tym usługowe, handlowe, rekreacyjne, sportowe), produkcyjnej i inne, wśród których są nieruchomości o funkcji gospodarczej oraz transportu i łączności. W badanym okresie najwięcej transakcji dokonano w ramach nieruchomości gruntowych zabudowanych o przeznaczeniu mieszkaniowym. Wśród nieruchomości zabudowanych o funkcji komercyjnej, stanowiących przedmiot analizowanych transakcji, znaleźć można było: biura, sklepy, budynki administracyjne, obiekty leczniczo-uzdrowiskowe, gastronomiczne, hotele. Natomiast w kategorii nieruchomości produkcyjnych znalazły się dwie hale produkcyjne wraz z zabudową towarzyszącą.

\section{WNIOSKI}

Nieruchomości stanowiące przedmiot transakcji kupna-sprzedaży w Uniejowie w latach 2007-2015 podzielone zostały według struktury rodzajowej. Najbardziej licznymi były te, które dotyczyły nieruchomości lokalowych, w większości położonych w nowej zabudowie wielorodzinnej. Wynikało to m.in. z uruchomienia sprzedaży mieszkań na rynku pierwotnym przez prywatnego developera, co uwidacznia się także w wyraźnym wzroście zainteresowania konsumentów nieruchomościami lokalowymi w roku 2013 i 2015. Sprzedaż nieruchomości niezabudowanych i budynkowych stanowiły znikomą liczbę. Transakcje rozproszone były po całej zurbanizowanej strefie miasta.

Najliczniej występującą formą zbywania nieruchomości w Uniejowie w badanym okresie była sprzedaż na wolnym rynku, pozostałe formy stanowiły zaledwie $7 \%$ wszystkich transakcji. W drodze przetargu Miasto w analizowanym czasie zbywało m.in. działki określane w Studium uwarunkowań i kierunków zagospodarowania gminy Uniejów jako rozwojowe obszary jednorodzinnej zabudowy mieszkaniowej. Analizy potwierdzają tendencję rozwoju zagospodarowania miasta w kierunku północnym. Dodatkowo status uzdrowiska ${ }^{24}$ wywołuje aktywność na rynku nieruchomości rekreacyjnych o funkcji leczniczo-uzdrowiskowej. Można zatem zauważyć, iż wpływ na rynek nieruchomości i lokalizację transakcji kupna-sprzedaży w analizowanym okresie miały m.in. zapisy Studium uwarunkowań i kierunków zagospodarowania przestrzennego Uniejowa, które dzielą obszar urbanizacji na poszczególne strefy ochrony uzdrowiskowej, rolniczej przestrzeni produkcyjnej, wartości kulturowych i ekologicznej.

${ }^{24}$ Operat uzdrowiskowy uzdrowisko Uniejów, 2011; Załącznik do Uchwały nr XXXII/182/2012 Rady Miejskiej w Uniejowie z dnia 23 sierpnia 2012 r. Statut uzdrowiska Uniejów, 2012. 
W badanym czasie dokonano 126 transakcji kupna-sprzedaży lokali mieszkalnych. W większości zrealizowano je na rynku pierwotnym, ich średnia powierzchnia użytkowa wynosiła $51,2 \mathrm{~m}^{2}$, a cena $3183,5 \mathrm{z} / \mathrm{m}^{2}$. Na rynku wtórnym z kolei średnia powierzchnia użytkowa wynosiła $45 \mathrm{~m}^{2}$, natomiast średnia cena za m² wynosiła 2906,1 zł.

Zdecydowana większość transakcji dotyczyła nieruchomości gruntowych zabudowanych niż niezabudowanych. Oprócz przeznaczenia na cele mieszkaniowe dokonywano także sprzedaży nieruchomości na biura, sklepy, obiekty leczniczo-uzdrowiskowe, gastronomiczne, hotele, co w dużej mierze związane jest z rozwojem uzdrowiskowym Uniejowa.

\section{Bibliografia}

Bryx M. (red.), Podstawy zarządzania nieruchomościami, Wyd. Poltex, Warszawa 2009.

Kodeks Cywilny (Dz.U. 2018, poz. 1025, 1104, 1629, 2073, 2244; Dz.U. 2019, poz. 80).

Kucharska-Stasiak E., Nieruchomość a rynek, Wyd. Naukowe PWN, Warszawa 1997.

Kucharska-Stasiak E., Nieruchomości w gospodarce rynkowej, Wyd. Naukowe PWN, Warszawa 2006.

Milewska-Osiecka K., Ogrodowczyk A., Budownictwo $i$ warunki mieszkaniowe na terenie miasta Uniejów, „Biuletyn Uniejowski” 2014, t. 3.

Obrót nieruchomościami w 2014, Główny Urząd Statystyczny, Warszawa 2015.

Operat uzdrowiskowy uzdrowisko Uniejów, 2011.

Pawlikowska-Piechotka A., Gospodarka nieruchomościami, Warszawa 1999.

Projekt Lokalnego Programu Rewitalizacji Gminy i Miasta Uniejów na lata 2017-2025, 2017.

Skoczeń J., 2015, www.strefynieruchomosci.blog.pl [dostęp: 5.05.2017].

Statut uzdrowiska Uniejów 2012, załącznik do Uchwały nr XXXII/182/2012 Rady Miejskiej w Uniejowie z dnia 23 sierpnia 2012.

Ustawa z dnia 21 sierpnia 1997 r. o gospodarce nieruchomościami (Dz.U. 2018, poz. 2204, 2348; Dz.U. 2019, poz. 270).

Wójcik T., Czeka Nas dużo pracy, wywiad z panem Józefem Kaczmarkiem, burmistrzem Uniejowa „W Uniejowie, Pismo Towarzystwa Przyjaciół Uniejowa”, red. M. Charuba i in., Uniejów 2015.

Zarządzenie nr 46/2013 Burmistrza miasta Uniejów z dnia 2 lipca 2013 r. w sprawie ogłoszenia o przetargu nieograniczonym na sprzedaż na własność nieruchomości gminy Uniejów, Uniejów 2013.

Zarządzenie nr 97/2015 Burmistrza Miasta Uniejów z dnia 8 października 2015 r. w sprawie ogłoszenia o II-gim ustnym przetargu nieograniczonym na sprzedaż działek z przeznaczeniem pod budownictwo mieszkaniowe jednorodzinne, Uniejów 2015.

Zmiana Studium uwarunkowań i kierunków zagospodarowania przestrzennego miasta i gminy Uniejów, Uniejów 2007. 


\section{Źródła elektroniczne}

http://prawoanieruchomosci.pl/ [dostęp:18.01.2017].

http://uniejow.pl/o-gminie/spolki-gminne/ [dostęp: 20.05.2017].

http://www.dzienniklodzki.pl/ [dostęp: 20.05.2017].

http://www.izc.pl/uniejow/nasz-osrodek.html [dostęp: 19.05.2017].

http://www.termalna.com.pl/ [dostęp: 19.05.2017].

http://www.uniejow.net.pl/ [dostęp: 19.05.2017].

\section{TRANSACTIONS ON REAL ESTATE MARKET IN UNIEJÓW IN 2007-2015}

\section{Summary}

The article presents the results of analysis of purchase-sale transactions concluded in the years 2007-20015 within the administrative boundaries of Uniejów. The aim of this study is to identify the types of real property being the object of purchase-sale transactions, including their locations, and to highlight the general situation on the real estate market in the analysed area.

Keywords: real estate, estate market, purchase-sale transactions, Uniejów

Data wpływu artykułu: maj 2019

Data akceptacji: czerwiec 2019 